\title{
Current Status and Prospective of Offshore Wind Power to Achieve Korean Renewable Energy 3020 Plan
}

\author{
Minkyu Park ${ }^{*} \cdot$ Seongjun Park ${ }^{* \oplus} \cdot$ Byungcheol Seong $^{* \oplus} \cdot$ Yeonjeong Choi $^{* \oplus} \cdot$ Sokhee P. Jung ${ }^{\dagger \oplus}$
}

Department of Environment and Energy Engineering, Chonnam National University, Gwangju

(Received December 8, 2020; Revised February 24, 2021; Accepted March 2, 2021)

\begin{abstract}
This review comprehensively reviewed floating offshore wind power generation technology, which is being newly developed as a mid- to long-term plan for wind energy. From the perspective of investment per megawatt (MW), offshore wind power is still about 50 percent more expensive than land wind power. Nevertheless, many advanced countries began to investigate the data because they wondered why they were immersed in development and investment, and why offshore wind facilities installed on the beach and floating offshore wind installed in the middle of the sea, unlike the land wind we knew. We looked at the basic principles of offshore wind power generation and the technologies used in facilities, and looked at the advantages and disadvantages of offshore wind power generation compared to land wind power generation, and what differences between fixed offshore wind farms and floating offshore wind farms. It is investigated whether it is a realistic plan to verify residents' opposition to the installation of offshore wind power facilities, the possibility of commercialization such as high operational management costs, and the feasibility of installing facilities for renewable energy 3020 as midto long-term goals. In addition, it compares foreign cases with offshore wind power development complexes in Korea, marine wind power generation complexes in operation, and high wind power in Scotland, the first floating offshore wind power in Ulsan, Korea, to overcome difficulties in installing facilities and suggest directions for domestic offshore wind power development. In addition, in Korea, where there are not many countries suitable for wind power generation unlike overseas, it was decided to investigate whether floating offshore wind power could be the answer as planned. The reason why the government is pushing for investment in renewable energy such as solar power and wind power is because energy sources from the sun are eco-friendly. However, the U.S. and Europe, which started the wind power project early, are having difficulty in handling the wings of wind power generators. The energy source looked at the contradictions caused by environmental pollution in the treatment of waste, although it was environmentally friendly, and investigated how waste was treated and utilized overseas. Compared to other countries that entered the offshore wind power business earlier, domestic power generation projects are in their infancy and should focus on developing technology and co-prosperity with neighboring residents rather than on excessive expansion.
\end{abstract}

Keywords: Offshore Wind Power, Floating Type, Renewable Energy 3020 Plan, Hywind, Wind Power Waste

The Korean text of this paper can be translated into multiple languages on the website of http:/jksee.or.kr through Google Translator. 


\title{
한국형 재생에너지 3020 이행계획 달성을 위한 해상풍력발전의 현재와 전망
}

\author{
박민규 $^{*} \cdot$ 박성준 $^{*}$ - 성병철 ${ }^{*} \cdot$ 최연정 ${ }^{*} \cdot$ 정석희 $^{\dagger}$ \\ 전남대학교 환경에너지공학과 광주캠퍼스
}

\begin{abstract}
요약: 본 논문은 풍력에너지의 중장기 계획으로 새롭게 개발되고 있는 부유식 해상풍력발전에 종합적으로 리뷰했 다. 메가와트 $(\mathrm{MW})$ 당 투자 관점에서 보면 해상풍력은 여전히 육상풍력보다 $50 \%$ 정도 비싸다. 그럼에도 불구하고 많은 선진국이 개발 및 투자에 발을 담그는 이유와, 우리가 알던 육상풍력과 다르게 바닷가에 설치된 해상풍력시 설, 바다 한가운데에 세워지는 부유식 해상풍력에 대한 궁금증이 생겨 자료를 조사하기 시작했다. 해상풍력발전의 기본적인 원리와 시설에 사용된 기술들을 살펴보고, 육상풍력발전과 비교하여 해상풍력발전이 가지고 있는 장단점 과 고정식 해상풍력시설과 부유식 해상풍력시설은 어떤 차이점이 있는지 조사했다. 해상풍력 설비 설치 시 발생하 는 주민들의 반대, 개발의 어려움, 높은 운영관리비 등 상용화 가능성, 경제성에 대한 시설 설치의 타당성을 검증 하고, 재생에너지 3020 이행계획의 중장기 목표로 부유식 해상풍력을 선정한 것이 현실성 있는 계획인가에 대해 조사하였다. 더불어 해상풍력이 발달한 외국사례와 국내에 운영 중인 해상풍력 발전단지, 운영 예정인 단지를 비교 하고, 최초의 부유식 해상풍력인 스코틀랜드의 하이윈드와 우리나라 울산에서 진행 중인 부유식 해상풍력과 비교 하여 시설설치에 따른 어려움을 극복하는 방안과 국내 해상풍력 발전 사업이 나아갈 방향을 제시하였다. 또한, 해 외와 다르게 풍력발전에 적합한 국토가 많지 않은 대한민국에서 풍력에너지 발전량을 계획한 대로 늘릴 수 있는 지, 부유식 해상풍력이 그 해답이 될 수 있는지 조사해 보기로 하였다. 정부가 태양광 풍력 등 신재생 에너지에 투 자를 추진하는 이유는 태양으로부터 비롯된 에너지원이 친환경적이라는 이유 때문이다. 하지만 풍력발전 사업을 일찍 시작한 미국과 유럽에서는 풍력발전기 날개 처리에 곤란을 겪고 있다. 에너지원은 친환경적이지만 폐기물 처 리에서 발생하는 환경 오염에 따른 모순적인 모습을 살펴보고, 해외에서는 폐기물을 어떤 방법으로 처리 및 활용 하는지 조사하였다. 상대적으로 일찍 해상풍력사업에 뛰어든 해외와 비교하여, 국내의 발전사업은 걸음마 단계이 며, 무리한 사업확장보다는 기술의 개발과 주변 주민들과 상생에 집중하여 계획을 추진해야 할 것이다.
\end{abstract}

주제어: 해상풍력, 부유식, 재생에너지 3020 이행계획, 하이윈드, 풍력 폐기물

\section{1. 서론}

전 세계적으로 친환경적이면서도 지속 가능한 에너지 개발 에 대한 관심이 뜨겁다. 청결하고 재생 가능한 에너지의 다양 한 공급원 중, 풍력 에너지는 많은 장점이 있는 특히 매력적 인 재생 에너지원이다. 풍력 발전은 바람의 힘으로 전기를 생산하는 시스템으로서, 이전의 풍차의 원리와 유사하다. 깨 끗하고 비교적 폐기물 발생이 적은 발전 방식이지만, 바람이 불지 않는 시간에 전기 생산이 단절되거나 저주파 소음 발생 의 문제가 있다.

IRENA의 보고에 의하면, 풍력 발전은 지난 20 년간 75 배의 성장을 하였다. 2018년 기준, 풍력 발전은 재생 에너지 발전 량의 $16 \%$, 세계 전기 생산량의 $5 \%$ 를 차지한다. 세계 전기
생산에서 수력 발전(16\%)이나 핵 발전(10\%)보다는 비중이 작지만, 태양광 발전( $2 \%)$ 보다는 월등히 높음을 알 수 있다. 2018년 한해 세계 풍력 발전량은 $1,263 \mathrm{TWh}$ 이며, 이중 육상 발전이 1,195 TWh (95\%)이고 해상 발전이 $68 \mathrm{TWh}(5 \%)$ 를 차지한다. 2019년 세계에 설치된 풍력 발전의 용량은 621 $\mathrm{GW}$ 이며, 이중 육상 풍력 발전이 $593 \mathrm{GW}(95 \%)$ 이고 해상 풍력 발전이 $28 \mathrm{GW}(5 \%)$ 를 차지하고 있다.

많은 나라에서 풍력에너지에 대한 투자가 진행되고 있다. 특히, 전 세계 설치 용량의 $95 \%$ 이상이 선진국과 주요 개발도 상국인 중국과 인도가 차지하고 있다.

2030년까지 유럽은 풍력 시장에 200억을 투자할 예정이며, 이 중 $60 \%$ 가 해상 풍력을 겨냥한 전력시장이다. 2050년까지 전 세계 전력 수요의 $20 \%$ 이상이 풍력 에너지로 충족될 것으 
로 추산된다.

우리나라에서도 이러한 흐름에 발맞춰 재생에너지 3020 이 행계획을 발표하였으며, 풍력 발전과 태양광 발전을 중심으 로 계획이 수립되었다. 2017년 기준으로 전체 풍력에너지의 발전량은 $1.2 \mathrm{GW}$ 이다. 하지만 이 계획에 따르면 2030년까지 $17.7 \mathrm{GW}$ 의 규모의 풍력발전을 달성해야 하며, 이중 해상 풍 력은 $13 \mathrm{GW}$ 를 차지한다.

2011년부터 2020년까지 10년 동안 전 세계의 육상과 해상 풍력에 대한 발전은 지속해서 진행되었다. 해상풍력은 육지 풍력에는 다소 뒤처져 있지만, 해상풍력 에너지 생산은 가속 화되기 시작했음을 알 수 있다. 해상 풍력 발전 기술이 성숙 함에 따라 해상 풍력 발전소가 점차 번성하기 시작하고 있다.

\section{2. 추진계획}

\section{1. 부유식 해상풍력을 선택한 이유}

정부는 재생에너지 3020 이행계획안을 발표했다. '재생에 너지 3020'은 2030년까지 재생에너지 발전량 비중 $20 \%$ 를 달 성하기 위한 것으로 문재인 정부 친환경 에너지 전환 정책의 핵심이다. 재생에너지 발전량 비중을 $20 \%$ 까지 늘리며, 누적 설비용량을 $64 \mathrm{GW}$ 까지 보급하며 신규 설비용량의 $95 \%$ 이상 을 태양광, 풍력 등 청정에너지로 공급할 계획이다. 그중 해상 풍력발전은 계획의 총 $30 \%$ 를 차지하며 3020 계획을 달성하 기 위해 중추적인 역할을 담당한다.

해상풍력발전은 육지가 아닌 수중에서 바람의 운동에너지 를 회전 날개에 의한 기계 에너지로 변환하여 전기를 만드는 방식이다. 육상발전보다 풍속이 평균 $70 \%$ 빨라 육상 발전보 다 발전효율이 높다. 육상풍력을 비교한 해상풍력의 장점은 무게 수백 톤에 달하는 풍력발전기를 바다의 거친 바람량에 끄떡없도록 단단히 설치하는 것이며, 바다에서 생산한 전기 를 육지로 손실 없이 전달하는 것이다.

이러한 해상풍력은 경제성 때문에 수심에 따라 공사 방식 이 달라진다. 깊은 바다로 나가면 바람이 많이 불고 넓은 공 간을 활용할 수 있지만, 공사비용의 상승으로 인해 쉽지 않다. 이를 대안한 방식이 '부유식 해상풍력'이다. 배처럼 띄운 구
조물에 발전기를 세우는 방식이며 수심과 관계없이 풍력발전 기를 설치할 수 있다. 세계 최초 부유식 해상풍력 발전 단지 가 스코틀랜드에서 상용화되었으며 일본은 실증단계를 거쳐 2023년 상용화 추진 중이다.

재생에너지 강국인 중국과 미국에서도 단지 조성을 검토 중이며, 브라질 같은 남미 국가들도 프로젝트 개발을 모색하 고 있다. 우리나라는 울산시가 세계 최고 수준의 해양플랜트 인프라를 활용하고 동해 가스전 등 지리적 장점을 내세워 단 지 조성 이니셔티브를 모색한다. '부유식 해상풍력'은 발전설 비 본체가 바닥에 고정되지 않고 수중에 띄워진 상태에서 전 기를 생산하는 방식이며 수심이 깊은 해상에 적용 가능하기 때문에 먼바다의 풍부한 바람 자원을 활용하고 육지에서 수 십 $\mathrm{km}$ 떨어져 민원이 적고, 기초 구조물 및 지질조사 관련 비용을 줄일 수 있는 장점을 보유하고 있어 정부는 2030년까 지 재생에너지 발전 비중 $20 \%$ 달성을 추진하며 '부유식 해상 풍력'에 주목하고 있다.')

\section{2. 육상 풍력발전 대비 해상풍력 에너지의 장점과 단점}

2007 년 세계 풍력에너지는 총 발전 전력의 약 $1 \%$ 이고 대부 분 육상풍력이었으며 2009년 말 해상풍력은 2,000 MW 수준 이었지만 지속적으로 확대되고 있다. 해상풍력의 필요성으로 는 풍력발전은 발전단지가 대형화될수록 경제성 역시 향상되 나, 육지에는 수백 $\mathrm{MW}$ 규모의 대형 단지를 건설할 수 있는 부지가 매우 제한적이며 단지 건설에 따른 민원 문제 역시 큰 장애로 작용하므로 풍력발전의 보급 확산이 제한적이다. 해상은 풍황자원이 우수하고 대형 발전단지 건설이 용이하 며, 단지 건설에 따른 민원도 육상보다 적다(Table 1).

\section{3. 해상풍력의 특징}

해상풍력발전기는 바다에 설치됨으로 인해 육상과는 달리 설계 단계에서부터 추가로 고려하여야 할 요소들이 다수 있다.

\subsection{1. 해상풍력 설계}

육지에 설치되는 풍력발전기에 작용하는 외력은 바람이지 만 바다에 설치되는 풍력발전기는 바람 이외에도 파도와 조

Table 1. Advantages and disadvantages of offshore wind power compared to onshore wind power.

\begin{tabular}{ll}
\multicolumn{1}{c}{ 장점 } & \multicolumn{1}{c}{ 단점 } \\
$\begin{array}{ll}\text { 해안에서 멀어질수록 풍속이 높고 바람이 균일하기 때문에 풍력발전 } \\
\text { 기의 수명이 증대된다. }\end{array}$ & $\begin{array}{l}\text { 설계, 설치 및 운전비용이 더욱 많이 소요된다. 육상풍력에서 터빈발전기 비용은 총 건설비용의 } \\
75 \% \text { 수준인데 해상은 약 } 33 \% \text { 수준이다. }\end{array}$ \\
\hline 해수면 위 난류층의 높이는 지상에서의 난류층의 높이보다 낮아 풍력 & 해상풍력은 전력망 연결 길이가 더 길고 보강이 필요하기 때문에 건설 및 연결 비용이 훨씬 많이 소 \\
터빈이 설치되는 위치에서 바람의 품질이 우수하다. & 요된다. 육상풍력 건설비용이 $2 \mathrm{M€/MW인데} \mathrm{해상은} \mathrm{약} 4 \mathrm{M€/MW}$ 정도로 높다. \\
\hline 해상풍력발전단지는 설치공간이 더욱더 넓고, 블레이드 속도가 증가 & 해상풍력은 부하가 높고, 부식 등 해양 조건을 만족하여야 하고, 기초건설 난이도 및 운용 측면에 \\
함에 따른 소음이 증가해도 주민 민원의 소지가 훨씬 적어지므로 더 & 서 더 높은 수준의 기술이 필요하다. 육상과 해상 풍력발전 비용 사이에 큰 차이가 있지만, 해상풍 \\
큰 용량의 풍력터빈을 설치할 수 있다. & 력기술 발전에 큰 노력을 기울이고 있다. 특히 풍력터빈, 기초, 건설 및 운용 등의 분야에 대한 기술 \\
& 개발이 지속해서 추진되고 있다. ${ }^{2)}$ \\
&
\end{tabular}




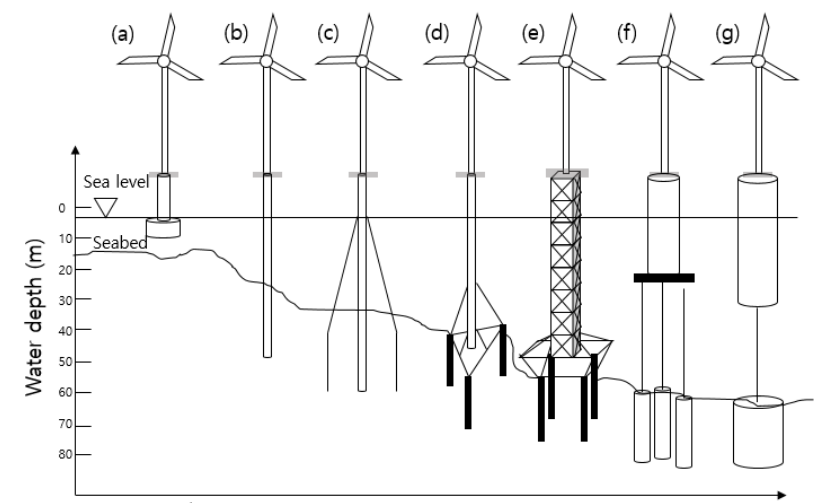

Fig. 1. Typical support structure options applicable at different water depths. (a) Gravity, (b) Monopile, (c) Monopile with guy wires, (d) Tripod, (e) Jacket/lattice structure, (f) Tension leg with suction buckets (ballast stabilized), (g) Buoy with suction anchor.

류 이동에 의한 물리력이 작용하므로 Multi-body dynamics 해석이 중요하다. 염분에 의한 부식과 해저 바닥에 존재하는 바위 등의 물체들이 거센 조류 또는 파도의 힘으로 풍력발전 기 수중 기초 구조물에 충돌하거나 바다를 운항하는 선박이 타워에 충돌하는 경우를 대비한 설계가 필요하다는 것이다. 바다에 설치되는 특성상 낙뢰 위험도가 매우 높으므로 이를 고려하여야 하며, 여름철에 발생하는 태풍의 영향을 필히 고 려한 설계가 되어야 한다. 해상 풍력발전기는 육상에 설치되 는 풍력발전기와 동일하게 타워 위에 발전기와 회전자가 설 치되지만, 타워를 고정하는 수중 기초가 추가된다. ${ }^{3)}$

풍력 발전기의 수중 기본 구조물의 유형은 다음과 같다.

(1) 중력식 기초(Gravity base foundation) - Fig.1의 (a)와 같이 가장 일반적인 기초 형식이며, 설치 수심은 $25 \mathrm{~m}$ 까지 적용 가능하다. 제작이 간단하고 경제적이며, 설치하기 위한 특수장비가 필요하다. 하지만 설치 시 소음과 진동이 발생하 며 공진 방지를 위한 기초구조물의 증량의 단점이 있다.

(2) 모노파일 기초(Monopile) - Fig.1의 (b), (c)와 같이 가장 많이 쓰이고 있는 기초이며 설치 수심은 $25 ~ 30 \mathrm{~m}$ 적용 가능 하며 대단위 단지의 경우 경제성이 좋다. 하지만 부재에 대한 피로 하중이나 부식의 문제와 제작 가능한 직경의 제한의 단 점이 있다.

(3) 재킷 기초(Jacket) - Fig. 1의 (e)와 같이 Tripod 타입으로 주로 사용되며 설치 수심은 20 80 m 적용 가능하고 해저지반 처리가 불필요하다. 모노파일이나 중력식에 비해 설치비용은 높으나 수평력에 따른 모멘트 저항에 유리하다. $5 \mathrm{MW}$ 급 이상의 대형 풍력발전기에도 적용할 수 있지만 타워와 연결 되는 부분의 피로 하중에 대한 주의 깊은 설계가 요구된다.

(4) 석션 기초(Suction pile) - Fig.1의 (d), (f), (g)와 같이 Tripod, Jacket type으로 구성 가능하며 설치 수심에 제약이 없다(최대 $1,600 \mathrm{~m})$. 설치가 비교적 간단하며 중장비가 불필 요하다는 장점이 있다. ${ }^{4}$

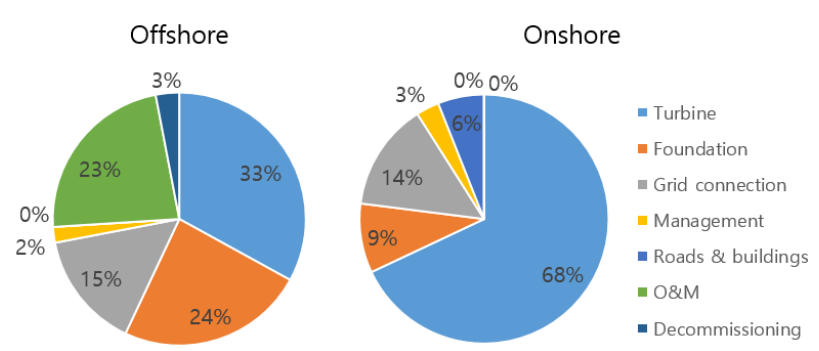

Fig. 2. Comparison of investment cost in land and offshore wind farm (EWEA, 2009).

\subsection{2. 해상풍력의 경제성}

해상풍력발전단지는 수중기초와 전력계통 연계 등 육상보 다 투자 비용이 많이 증가하므로 대규모발전단지의 건설을 통한 경제성 확보가 필요하다.

해상풍력발전단지 건설비용은 수심 및 육지와의 이격거리 등에 의해 크게 영향을 받는다.

유럽은 해상풍력발전단지 건설 및 운영 실적이 우수하며, 설치 수심이 주로 6 10 m 내외이다. 덴마크 Horns Rev 및 스웨덴 Lillgrund 해상풍력발전단지는 MW당 약 30 억 원의 건설비가 투자되었다. ${ }^{5)}$

위에 그림(Fig. 2)은 육상과 해상 풍력발전단지의 건설 투자 비를 비교한 것으로서 해상의 경우 총투자비에서 발전기가 차지하는 비중은 육상 대비 $50 \%$ 이나, 기초공사비와 유지보 수 비용이 차지하는 비중이 큰 폭으로 증가함을 알 수 있다. 전력계통 연계비는 해상풍력발전단지와 육지와의 이격거 리 및 수심 등에 의해 큰 차이를 보이며, 일반적으로 총 건설 비용의 $15 \%$ 정도를 차지하는 것으로 알려져 있다.

부품 교체가 필요할 경우 육상은 차량을 이용하여 비교적 용이하게 대응이 가능하지만 해상은 선박을 이용하여 부품을 운송하여야 하므로 추가적인 비용 발생하게 된다. 해상풍력 발전단지 건설에서는 풍부한 Track Record를 확보하여 신뢰 성이 검증된 기기의 선택이 중요한 요소이다. ${ }^{\text {) }}$

\section{4. 해상풍력 반대 의견}

\subsection{1. 해상풍력의 주요 민원 현황}

우리나라 서남해 지역에서는 현재 2,460 MW 규모의 해상 풍력 개발사업이 진행 중이다. 하지만 풍력발전소가 들어서 면 통항 금지 구역이 생겨 어장이 축소될 것이라 우려하는 어민들이 시위를 벌이고 있다. 이처럼 해상풍력 발전의 주된 걸림돌은 부지선정 이후에도 지속하는 주민들의 민원이다. 주민 의견을 수렴한 결과 주요 민원은 조업 감소, 생태계 영 향이다. 생계를 위협받는 주민들의 민원을 무시하고 사업을 진행하는 것은 불가능하다. ${ }^{7)}$

\subsection{2. 해외에서의 사례 조사}

풍력발전 선진국인 유럽에서는 이러한 주민들과의 협조를 
어떠한 방식으로 이루어 냈는지 대규모 해상풍력을 운영중인 영국의 사례를 조사했다. 영국에서도 일찍 해상풍력 사업을 시작하면서 어민들의 상생 방안을 모색했다.

조업량 감소 문제에 대해서 다양한 접근으로 어민들과 공 존 가능성을 찾았다. 해상 풍력 기초 구조물, 어초형 세굴방지 공, 인공 어초 등을 활용하여 수산자원을 조성하였다. 또한 제한적이지만 영국, 스페인 등에서는 어업권도 보장하였다. ${ }^{8)}$

\subsubsection{1. 생태계 영향}

해상풍력 발전의 주된 반대 의견 중 하나는 환경단체의 반 대이다. 독일과 노르웨이와 같은 일부 국가에서는 환경보호 단체 및 시민들의 반대로 인해 육상풍력발전이 거의 중단된 상태이다. 따라서 해상풍력발전도 이러한 우려로부터 자유로 울 수 없다. 해상풍력 주변 생태계 조사에 따르면 종 다양성 은 감소하였지만 전체 어류 개체 수는 증가하였다. 이는 해상 풍력 발전 주변에 인공 어초를 설치하였고, 해상풍력 구조물 이 집어 기능을 하여 해양생태계 긍정적 영향을 주었기 때문 이다. 하지만 이는 풍력 단지 내 어업을 금지하였기 때문에 생긴 현상이라고 볼 수 있다.

\subsubsection{2. 풍력발전 토양 오염 우려}

풍력발전은 친환경에너지이지만 설치, 운영과정에서 오염 물질이 발생한다. 풍력발전기의 부식을 방지하기 위해 알루 미늄(Al), 아연( $\mathrm{Zn})$, 인듐(In)이 사용되는데 이는 풍력발전소 주변 토양오염의 원인이다. 벨기에 북해 지역에서 해상풍력 발전이 주변 토양오염에 미치는 영양을 알아보기 위해 아연 농도 측정실험을 진행하였다. 풍력발전 인근 $(37.5 \mathrm{~m}$ 간격) 에서는 토양 오염의 농도가 $4.4 \mathrm{mg} / \mathrm{kg}$ 로 측정되었고, 풍력 발전에서 떨어진 곳 $(300 \mathrm{~m} \sim 500 \mathrm{~m})$ 에서는 $4.9 \mathrm{mg} / \mathrm{kg}$ 로 측정 되었다. 이는 토양오염 우려 기준 $300 \mathrm{mg} / \mathrm{kg}$ 보다 낮은 수치 이다. ${ }^{9)}$

\subsection{3. 부유식 해상풍력}

부유식 해상 풍력도 고정식 해상풍력과 마찬가지로 바다에 서 운영되기 때문에 어민들과 바다 생태계 문제를 피해 갈 수 없다. 하지만 부유식 해상풍력은 육지에서 제작한다는 특 성 때문에 기존의 고정식 해상 풍력 건설 과정에서 발생하는 환경적 이슈를 피해 갈 수 있다. 또한 해안선에서 멀리 떨어 진 곳에 설치가 가능하여 소음, 주변 경관 민원으로부터 자유 롭다. 현재 울산에서 추진 중인 부유식 해상풍력 발전은 육지 로부터 약 $46 \mathrm{~km}$ 지점 떨어진 해상에서 설치된다. 또한 터빈 의 설치 간격이 넓고 조류가 육지와 해안가보다 적게 분포하 기 때문에 육상 및 해상 풍력에 비해 조류충돌 빈도수가 적다. 하지만 여전히 조업 구역과, 블레이드 폐기물, 소음, 진동으 로 인한 생태계 영향에 대한 이슈는 여전히 해결해야 할 문제 이다.

\section{5. 높은 운영관리비에도 불구하고 전 세계적으로 개발하는 이유는 무엇인가?}

\subsection{1. 부지 선정의 자유}

풍력발전기를 설치하기 위해서는 설치가 가능한 부지가 필 요하다. 좁은 국토 면적을 가지고 있는 우리나라에서는 육상 풍력이 적합하지 않아 해상풍력으로 초점을 맞추고 있다. 하 지만 해상풍력을 설치할 수 있는 부지도 한정되어 있다. ${ }^{10)}$ 정부가 추진하는 전체 풍력발전 용량 $(17.7 \mathrm{GW})$ 을 달성하 기 위해서는 서남해 해상풍력 실증단지 기준 $\left(60 \mathrm{MW} / 14 \mathrm{~km}^{2}\right)$ 으로 $4,140 \mathrm{~km}^{2}$ 의 면적이 필요하다.

해상풍력으로만 발전용량을 맞춘다면 우리나라 해안선은 풍력발전기로 가득 차 버릴 것이다. 하지만 부유식 해상풍력 은 해안선으로부터 먼 곳에 떨어진 심해에도 설치가 가능하 기 때문에 부지 선정으로부터 자유롭다.

\subsection{2. 해상풍력발전 경제성}

현재 운영 중인 스코틀랜드의 하이윈드는 $30 \mathrm{MW}$ 규모의 설비 설치 비용으로 약 3,000 억 원을 투자하였고, 일본에서는 $6 \mathrm{MW}$ 규모의 설비 설치비용으로 800 억 원의 투자 비용을 예상하고 있다. 우리나라에서는 현재 울산에 $1 \mathrm{GW}$ 규모의 단지 조성 계획이 진행 중이고 총 사업비는 6 조 3 천억 원이다. $1 \mathrm{MW}$ 당 투자 비용은 약 63 억 원에서 130 억 원 수준이다. 해상 풍력의 $1 \mathrm{MW}$ 당 설치 비용은 약 50 억 원이고, 육상풍력의 1 MW당 설치 비용은 약 16 억 원이다. ${ }^{11)}$ 부유식 해상풍력은 다른 풍력발전과 비교하였을 때 설치비용 면에서 큰 비용이 든다.

다른 에너지원과 비교하여도 큰 차이를 보인다. 최근에 지 어진 원전 신고리 3,4 호기는 $1.4 \mathrm{GW}$ 규모에 3 조 7,500억 원 이 들었다. 이는 $1 \mathrm{GW}$ 당 2 조 6,785 억 원이다. 현재 울산에서 추진 중인 부유식 해상풍력과 비교하였을 때 설치 비용이 절 반보다 적게 든다. 또한 원자력과 $\mathrm{LCOE}$ (전 주기 동안의 발전 량 대비 전 주기 동안의 비용)을 비교할 때 풍력발전은 153.9 원/kWh, 석탄 화력은 62.32 원 $/ \mathrm{kWh}$ 원자력은 46.86 원 $/ \mathrm{kWh}$ 로 전력 단가 차이가 크다. ${ }^{12)}$ 현재 국내 풍력발전 대부분이 육상풍력발전임을 고려하면 부유식 해상풍력을 확대할 시 전 력 단가가 큰 폭으로 상승할 것이다.

\subsection{3. 낮은 경제성에도 개발하는 이유}

높은 초기 설치 비용과 전력 단가에도 세계적으로 부유식 풍력발전을 개발 중이다. 다른 에너지원과 비교하여 차별적 인 이점이 있기 때문이다. 첫 번째는 친환경적이다. 석탄과 천연가스 석유를 이용한 화석자원을 통한 발전시설은 필연적 으로 온실가스 발생을 동반한다. 이는 곧 온실가스로 인한 기후변화를 유발하여 자연재해, 평균 기온상승, 이상기후 등 인류에 큰 위협을 초래한다.

하지만 풍력발전은 에너지 발전의 원천이 태양에너지이기 때문에 탄소 발생은 0 이다. 두 번째 이유는 규모의 경제이다. 


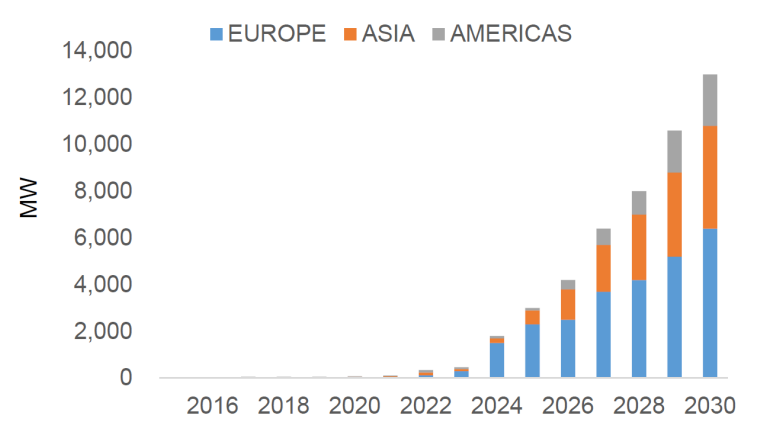

Fig. 3. Floating offshore wind market outlook by Equinor.

Equinor는 현재 부유식 해상풍력발전 용량은 매우 미미한 수 준이지만 2030년까지 부유식 해상풍력발전 용량이 $13 \mathrm{GW}$ 에 이를 것으로 예상하였다(Fig.3). 풍력발전내 비율은 작지만 빠르게 증가하고 있다.

부유식 해상풍력의 비용은 기존의 해상풍력과 달리 유지보 수 및 관리(31.3\%)가 터빈(16.7\%) 보다 많은 부분을 차지한 다. 설치 비용이 많이 들고 유지관리 비용은 적게 드는 기존 의 풍력발전과는 다르다. 부유식 해상풍력의 비용을 줄이기 위해서는 고정비용과 비용면에서 큰 비율을 차지하는 유지관 리 및 보수비용을 줄일 필요가 있다. 고정비용은 기존 풍력발 전 공급망을 활용하고 부유식 해상풍력은 건설단계가 간단하 기 때문에 설치용량이 증가한다면 비용 절감이 가능하다. 유 지관리 및 보수 비용은 기술 발전을 통해 절감할 수 있다. ${ }^{13)}$

해상풍력 터빈의 운용, 점검 및 유지를 $\mathrm{AI}$ 와 자동화 시스템 을 이용하여 실행한다면 작업시의 위험을 피할 수 있고, 풍력 과 파고가 강한 해상 위에서 시스템을 보다 효율적으로 제어 가능하다. 또한 강풍이나 해일을 기상 데이터를 이용하여 미 리 예측하여 손상이 일어나기 전에 미리 준비할 수 있다. ${ }^{14)}$ 따라서 지속적인 투자와 기술 개발을 진행한다면 규모의 경 제가 가능하다.

2016년 미국에서 가동된 $30 \mathrm{MW}$ 블록 아일랜드 해상풍력 발전소의 전력 단가는 275 원 $/ \mathrm{kWh}$ 이지만, 새롭게 진행되는 Vineyard Wind 해상풍력 사업 전력 단가는 73.45 원 $/ \mathrm{kWh}$ 이 다. ${ }^{15)}$ 또한 2010 년 대비 풍력 발전의 단가 하락률은 $49 \%$ 로 전력 단가가 빠르게 하락하고 있고, 2020년 대비 2030년 부유 식 해상풍력 전력 단가는 $60 \%$ 이상 하락할 것이다. ${ }^{16)}$ 유럽의 부유식 해상풍력 전력단가 예측 자료는 2020 년에는 $\mathrm{kWh}$ 당 약 300 원 수준이지만 2030년 전력단가는 $\mathrm{kWh}$ 당 약 100 원 수준으로 하락할 것이라 예상하고 있다(Fig.4).

위의 전망과 사례로부터 규모의 경제와 기술 발전을 통해 부유식 해상풍력의 경제성 확보가 가능하다.

부유식 해상풍력은 환경단체, 어민 등 시민들의 반대에서 육상, 해상 풍력발전보다 자유롭다. 신재생에너지의 선두주 자인 유럽에서는 독일과 노르웨이와 같은 일부 국가에서는 시민들의 반대로 인해 육상풍력발전이 대부분 중단되었다. 또한 해상풍력발전은 어민, 환경보호단체, 해안거주민들의

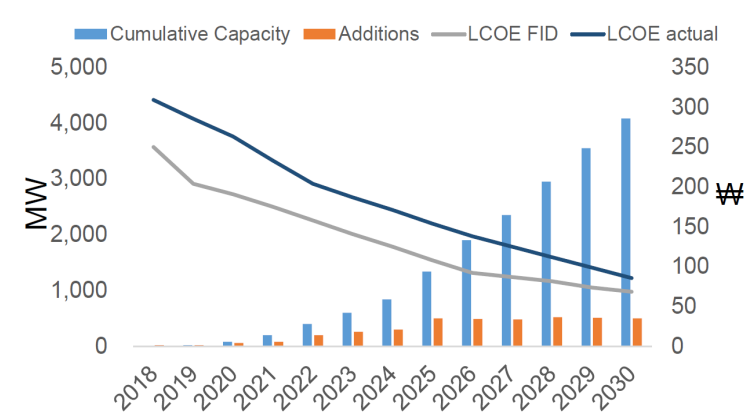

Fig. 4. Wind Europe's floating offshore wind energy: a policy blueprint for Europe (October 2018). LCOE of floating offshore.

반대가 증가하고 있다. 부유식 해상풍력은 해안에서 멀리 떨 어진 곳에 설치가 가능하여 주변경관 훼손으로부터 자유롭 고, 심해에도 설치가 가능하여 해상풍력과 비교하여 주민들 과의 합의를 원만하게 진행할 수 있다. ${ }^{17)}$

\section{6. 세계 최초 부유식 해상풍력 발전 하이윈드의 상용화}

\subsection{1. 해상풍력 선진국}

이탈리아, 노르웨이, 미국, 일본 등에서 부유식 해상풍력 파 일럿 프로젝트가 존재하지만, 하이윈드 스코틀랜드는 세계 최초의 발전사업으로 현재 스코틀랜드의 전력망에 전기를 공 급하고 있다. 이 풍력발전기의 이름은 '하이윈드 파일럿 파크 (Hywind pilot park)'이다. ${ }^{12)}$ 이 풍력발전단지는 5 개의 대형 풍력터빈(6 MW)을 포함하며 Masdar와 제휴하여 노르웨이의 정유기업 'Stotoil'에서 운영한다. 각각의 터빈은 높이 15.24 $\mathrm{m}$ 이상, 무게는 110 ton 이상인 흡입 앵커를 사용하여 해저에 부착된다. 흡입 앵커는 터빈이 파도와 함께 흔들릴 때 선박 앵커와 같이 터빈이 원래 위치에서 너무 멀리 떨어지지 않도 록 방지하는 역할을 한다.

Hywind pilot park는 기존 해상 풍력발전기처럼 기둥을 해 저 지반에 고정하는 것이 아닌 ‘하이윈드’라는 풍력발전기를 바다 위에 띄워 설치한다. 유럽 해상풍력 잠재력의 $80 \%$ 는 해 저 수심 $60 \mathrm{~m}$ 이상인 곳에서 집중되어 유럽 ${ }^{18)}$ 에서만 4,000 $\mathrm{GW}$ 의 잠재력이 있는 것으로 추정되며 $30 \mathrm{MW}$ 풍력발전소는 약 20,000 가구에 전력을 공급할 것으로 예상된다.

더 경쟁력 있는 해상풍력을 갖추기 위해 터빈 제조업체는 북해의 험난한 해역에서 강한 폭풍을 견딜 수 있는 거대한 기계를 제조하고 있지만, 해저에 터빈을 못으로 박을 수 있는 견고한 기초, 특수설비 및 선박에 대한 비용 또한 감수해야 할 부분이다. 업계 전문가들은 거대 부유식 풍력터빈이 저렴 한 가격으로 우수한 풍력 조건을 가진 지역에 접근할 수 있다 면 틈새시장을 개척할 수 있다고 말한다.

\subsection{2. 국내 해상풍력 환경}

최근 '에너지 3020 정책'을 시작으로 신재생 에너지 비중을 
늘리기 위해 노력 중인 우리나라도 풍력발전에 상당한 노력을 기울이고 있으며 삼면이 바다인 점을 잘 활용한다면 우리나라 는 풍력발전 강국으로 성장할 수 있을 것이다. 하지만 비교적 풍속이 강한 동해나 남해는 수심이 깊고 해저가 불균형하여 대규모 고정식 해상풍력단지를 설치하기에는 어려움이 있고, 서해안은 수심이 낮지만, 동해에 비해 풍속이 약한 편이다.

그래서 포항 거제, 포항 호미곶 제주도 수역은 해안선에서 $20 \mathrm{~km}$ 내외로 가까워 해저케이블 비용이 적으며, 수심이 깊 고 풍황이 우수해 부유식 해상풍력 개발에 유리하다. 더군다 나 우리나라는 조선 해양플랜트 강국으로서 부유식 해상풍력 관련 부유체, 계류 시스템, 해저케이블 등 다수의 부품이 국산 화되어있다. ${ }^{19}$

우리나라는 앞으로 해상풍력에 대한 연구개발과제가 진행 중으로 울산 해상 $4 \mathrm{~km}$ 해역(수심 $50 \mathrm{~m}$ )에 $750 \mathrm{~kW}$ 급 파일럿 시스템을 설치할 계획이다.

\section{7. 고정식 해상 풍력과 부유식 해상풍력의 차이}

육상풍력발전보다 해상풍력발전에 관심을 쏟은 이유는 해 양은 육지보다 바람을 막는 장애물이 적어 바람의 난류와 풍 속 변화가 적기 때문이며, 그로 인해 해상풍력발전은 육상풍 력발전보다 1.5 2배로 발전량이 많다. 하지만 고정식 풍력발 전의 기술로는 수심이 낮은 해안가 근처에만 풍력발전기를 설치할 수밖에 없고, 이를 보완할 수 있는 기술이 바로 부유 식 해상풍력이다. 고정식 해상풍력 플랫폼의 경우 터빈 가격 이 가장 비싼 품목으로 전체 비용에 약 $31.8 \%$ 가 기여하고 있으며, 조립·설치(19.3\%), 하부구조·기초(14.7\%) 순이다. 부유식 해상풍력 플랫폼의 경우 하부구조와 기초가 가장 비 싼 부품(36.2\%)이다. 터빈과 그 조립 및 설치는 전체 비용의 약 $22.1 \%, 11.1 \%$ 를 차지한다. 고정식 플랫폼의 하부 구조와 기반에 대한 높은 비용 때문에 고정 하부 구조와 부유식 해상 풍력 프로젝트 사이에는 전체적인 비용 차이가 크게 나타나 게 되고, 부유식은 고정식에 비해 해저 바닥에 설치하는 비용 을 상당히 줄일 수 있어 경제적인 면에서도 긍정적이다.

부유식 해상풍력 발전기가 넘어지지 않는 이유는 원통형 부표로 이루어진 하이윈드 하부가 최대 $40 \mathrm{~m} / \mathrm{s}$ 풍속과 $20 \mathrm{~m}$ 의 파고를 견딜 수 있도록 설계되어 있기 때문이다. 이 부표 는 해저 지반에 연결된 3 개의 고정장치 및 케이블로 연결되어 있으며, 주변의 하이윈드와 연결장치를 같이 공유하기 때문 에 서로의 중심을 잡아줄 수 있다. 그렇기 때문에 기존 방식 과 달리 깊은 바다에서도 설치가 가능하며, 기존에 접근이 불가능했던 먼 지역까지 영역을 확장하여 최대 수심 $800 \mathrm{~m}$ 까 지 적용이 가능하게 되었다.

\section{8. 전 세계적인 해상풍력 발전 현황}

\subsection{1. 탐라 해상풍력(상업용 풍력단지)}

두산중공업과 한국남동발전이 협업하여 2017년 9월 준공
된 국내 최초의 상업용 해상풍력단지로, $3,000 \mathrm{~kW}$ 규모의 발 전기 10 대가 설치되어 제주에서 운영 중이다. 준공 이후 1 년 간 발전량 $86,049 \mathrm{MWh}$, 가동률 $99 \%$, 이용률 $32.7 \%$ 를 기록 하며 예상했던 수치를 웃도는 모습을 보여줬으며, 매출액 또 한 267억 6,000만 원을 벌어들이며 상업용 해상풍력의 대표 성공사례로 자리매김하였다.

하지만 최근 안전 발판의 유실 및 작업자가 착용하는 구명 조끼의 유통기한 경과와 같은 부실한 안전관리로 인해 작업 자가 사망하는 사건이 발생하였으며, 10 대의 시설 중 1 대가 화재에 휩싸이는 등, 준공된 지 5 년도 채 되지 않아 문제점들 이 드러나고 있다. ${ }^{20)}$

\subsection{2. 전라북도 고창군의 서남해 해상풍력 실증단지}

전북 부안군과 고창군 해안에 있는 서남해 해상풍력 실증 단지는 면적이 $14 \mathrm{~km}^{2}$, 총 $60 \mathrm{MW}$ 규모로 이루어져 있다. 여기서 생산되는 연 $155 \mathrm{GWh}$ 의 전력은 $27.6 \mathrm{~km}$ 길이의 해저 케이블을 통해 고창군과 부안군으로 보내진다. 이는 지역 전 기 사용량의 $15 \%$ 를 차지하는 생산량이다. 현재 20 기의 발전 시설 중 5 6기만이 전력을 생산하는데, 이는 바람의 세기가 $2 \sim 3 \mathrm{~m} / \mathrm{s}$ 로 매우 약하게 불어오기 때문이다. 이에 한국 해상풍 력 관계자는 제주 탐라 해상풍력 발전 단지보다 시설의 이용 률은 낮지만, 블레이드의 크기가 크기 때문에 전력을 생산하 는 효율이 높다고 말했다. 정부는 2028년까지 $2.4 \mathrm{GW}$ 규모까 지 발전용량을 늘린다고 계획했지만, 이를 실현하기 위해서 는 $3 \mathrm{MW}$ 터빈이 800 기가 필요하므로 상당한 부지 면적과 예산이 들어갈 것으로 예상된다. 이와 같은 문제들을 해결하 기 위해서는 터빈의 생산효율을 높이는 기술의 개발이 필요 할 것으로 보인다. 실증 단지에 전혀 발전이 없던 것은 아니 다. 블레이드의 회전 직경이 기존의 $100 \mathrm{~m}$ 에 비해 $134 \mathrm{~m}$ 로 커졌기 때문에 바람을 이용하는 비율이 $25 \%$ 정도 높아졌으 며, 시설을 지탱하는 구조물 또한 '석션버켓' 이라는 신기술 이 도입되었다. 기존의 구조물은 암반층까지 파일을 박는데 비해 석션버켓은 지반에 꽂아 고정하는 방식으로 공사 기간 과 비용을 대폭 감소시켰다. ${ }^{21)}$

\subsection{3. 해외 현황}

대한민국보다 일찍 풍력발전산업에 뛰어든 미국은 2050년 까지 발전용량을 $86 \mathrm{GW}$ 규모까지 늘릴 계획을 세웠다. 세부 계획으로는 2020년에 $0.01 \mathrm{GW}, 2023$ 년에 $0.3 \mathrm{GW}, 2024$ 년부 터는 매년 2.5 4. GW 규모의 해상풍력단지를 동부 연안에 설치한다고 밝혔다. 기술의 발전으로 전기료는 갈수록 낮아 질 전망이며, 2030년까지 $22 \mathrm{GW}$ 규모를 달성할 경우 개발비 용은 약 500 억 달러로 추정된다. 현재 동부 연안의 해상풍력 발전이 활발한데, 서부 연안에 비해 낮은 수심이 저렴한 고정식 발전시설의 설치를 쉽게 하기 때문이다. 수심이 깊은 해안에 설치될 부유식 발전시설의 개발이 중요시될 것으로 보인다.22) 
영국의 보리스 존슨 총리는 코로나바이러스로 인해 타격을 입은 경제를 회복시키기 위한 방법으로 풍력발전을 선택했 다. 2020년 10월 6일에 열린 집권 보수당 연례전당대회 연설 에서 약 1 억 6,000만 파운드를 투자하여 2030년까지 해상풍 력발전 $40 \mathrm{GW}$ 로 확대할 계획을 밝혔다. 총리는 이와 같은 계획을 발표하며 영국의 모든 가정의 전력 필요량을 풍력발 전을 통해 채우겠다는 포부를 밝히기도 하였다. ${ }^{23)}$

2015년까지 $5 \mathrm{GW}, 2020$ 년까지 $30 \mathrm{GW}$ 용량을 목표로 한 중국의 경우 신규설치용량 $1,342 \mathrm{MW}$ 로 전체의 $28 \%$ 를 차지 하여, $1,728 \mathrm{MW}$ 의 영국에 이어 2 위의 자리를 지키고 있다. 이에 중국은 2025년까지 풍력설비 연간 $50 \mathrm{GW}$, 이후 연간 최소 $60 \mathrm{GW}$ 용량의 시설을 설립하겠다는 목표를 밝혔고, 이 계획대로라면 2060년에 중국의 풍력 설비 용량은 $3,000 \mathrm{GW}$ 에 다다를 것으로 보인다.

독일의 철도회사인 Deutsche Bahn에선 Amrumbank West offshore wind farm에서 생산되는 전력에 대해 2024년에 시작되 어 2039년까지 운영될 15년 구매계약을 체결했다. Amrumbank West는 독일 북해 헬리골랜드 해안에서 약 $30 \mathrm{~km}$ 떨어진 곳에 있으며, 풍력 발전소의 80 개의 풍력 터빈이 2015년부터 가동되 고 있다. Deutsche Bahn에 대한 공급 물량은 18 개의 풍력 터빈 의 용량, 즉 해상 풍력 발전 연간 용량의 약 4 분의 1 로 약 $260 \mathrm{GWh}$ 정도가 필요하다. ${ }^{24)}$

일본 정부는 조만간 지바현과 아키타현 지정지구의 해상풍 력발전소 운영 신청 접수를 시작할 것으로 보인다. 이 분야에 대한 경험이 부족한 일본에는 기술의 개발과 수익성을 시험 하는 사업이 될 것이다. 관련 법령에 따라 지정된 지역은 지 바 현에 위치한 초시 시의 앞바다 한 곳, 아키타 현에 위치한 노시로 시, 미타네 정, 오가 시의 앞바다 한 곳, 아키타 현에 위치한 유리혼조 시의 앞바다 두 곳 등 총 4곳이다. 일본 정부 는 조만간 신청 요건 등 입찰 접수 계획을 발표할 계획이다. 일본 정부는 지난 7월 2030년까지 해상풍력발전소와 함께 10 기의 원자로와 맞먹는 1,000 만 $\mathrm{kW}$ 의 발전용량을 달성한다는 계획을 내놨다. ${ }^{25)}$

\section{9. 풍력발전 폐기물(폐기물 현황, 폐기물의 재활용)}

\subsection{1. 풍력발전 폐기물 처리현황}

최근 풍력발전에 대한 관심이 커지면서 공기업뿐만 아니라 대기업에서도 풍력발전 사업에 뛰어들고 있지만, 수명이 다 한 발전시설의 블레이드를 처리하는 데 어려움이 있을 것이 라는 의견이 제시되고 있다. 미국이나 영국의 경우 대한민국 보다 일찍 풍력발전사업을 시작하여, 노후화되어 처리해야 할 발전시설들이 나타나고 있다. 하지만 여기서 나온 블레이 드를 처리하는 것이 마냥 쉬운 일은 아닌 듯 보인다. 1990년 대에 풍력 발전 사업을 크게 확대한 미국의 경우 한 해에 약 8,000 여 개의 블레이드가 폐기되고 있다. 블레이드 폐기물은 매년 증가하여 2050년에는 2,000만 톤에 달할 것으로 예상된

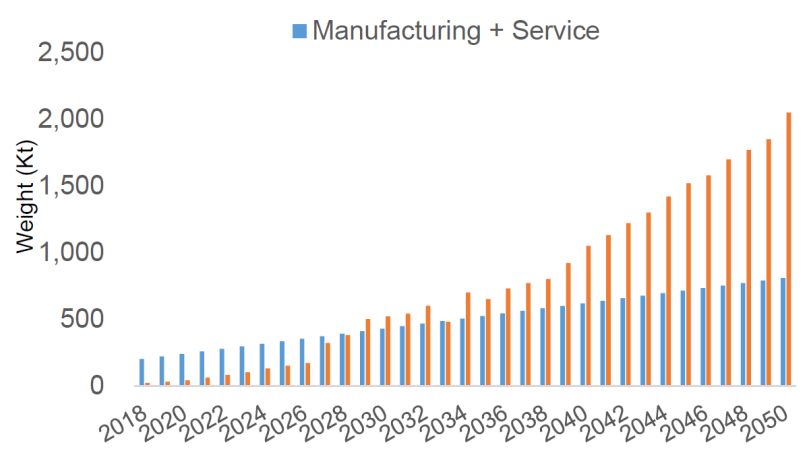

Fig. 5. Wind turbine blade waste in 2050 (Liu, P., \& Barlow, C. (2017)).

다(Fig.5). 여기서 문제는 이 수많은 블레이드를 땅에 묻는 것 말고는 다른 방법이 없다는 것이다. 소각하여 처리하는 방법은 그 과정에서 유해물질이 발생하여 환경을 오히려 오 염시키고, 재활용하기에는 들어가는 비용이 만만치 않아 진 행이 어려운 실정이다. ${ }^{26)}$

\subsection{2. 풍력발전 폐기물의 재활용}

덴마크의 Miljøskærm이라는 기업은 노후화된 풍력 발전 시 설의 블레이드를 방음벽의 재료로 재활용할 방법을 발견했 다. 시설에 사용되는 블레이드는 무게가 가볍고, 내구성이 좋 아야 하므로, 유리섬유를 사용하여 만들어지는데 이 유리섬 유를 재활용하기가 매우 까다롭다. Miljøskærm 기업은 유리 섬유의 내구성과 기존 방음벽에 사용되었던 물질과 비슷한 특성을 띠는 것을 활용하여 유리섬유를 활용한 방음벽을 제 작하기로 한다. 이는 시중에 유통되는 제품보다 에너지 소비 량은 $40 \%$, 이산화탄소 배출량은 약 $60 \%$ 정도 낮은 것으로 나 타났다. 또한, 유리섬유의 강한 내구성 덕분에 기존의 방음벽 과는 달리 정기적인 관리가 필요하지 않다는 장점이 있다. ${ }^{27)}$

\subsection{3. 블레이드 폐기물의 재활용사례}

\subsubsection{1. 네덜란드의 Wikado 놀이터}

네덜란드의 건축회사 2012 Architecten은 5개의 폐기되는 블레이드를 조각내어 아이들이 놀 수 있는 놀이터 공간을 설 계했다. 블레이드 조각들은 워터 타워, 워터슬라이드 타워, 등산 타워 등으로 재활용되었으며, 놀이터는 2007년에 완공 되어 메이도른 어린이재단 회원들을 위해 운영된다.

\subsubsection{Rewind Willemsplein}

네덜란드의 건축회사인 Superuse Studio는 폐기 블레이드 를 건축 분야에 사용하여 문제를 해결하고자 하였다. 소각 예정이었던 블레이드 9 개를 활용하여 로테르담에 공용 좌석 을 설치하였으며, 그 지역의 항구 관광 보트에 탑승을 기다리 는 승객을 위해 사용되고 있다. 좌석이 위치한 공간이 행사와 같은 이유로 필요한 경우 이동이 가능하여 공간 활용 면에서 도 뛰어난 모습을 보인다. 


\subsubsection{Rewind Almere 공용벤치}

Superuse Studio는 $30 \mathrm{~m}$ 블레이드 4개를 활용하여 Almere의 버스-열차 환승역 심터 건설을 진행하였다. 2 개의 거대한 블레 이드가 지붕 역할을 하고, 가운데 축과 가까운 무겁고 두꺼운 부분은 지붕을 지지하는 기둥 역할을 하게 된다. 날의 끝부분 은 좌석으로 활용되고, 원형인 끝부분은 화분으로 재탄생되어 블레이드의 모든 부분을 버리지 않고 모두 이용한다. ${ }^{28)}$

\subsection{0. 전망}

\subsection{1. 현재 추진 중인 사업}

(1) 울산 부유식 해상풍력 - 울산 앞바다에 위치한 동해 가 스전 인근에서 $200 \mathrm{MW} / 1 \mathrm{GW}$ 급 부유식 해상풍력단지가 설 치될 예정이다. 울산시는 설치 해역의 수심과 연 평균 풍속이 부유식 해상풍력발전에 적합하다는 점을 내세우며 프로젝트 를 추진 중에 있으며, 2019년 1월, 국내외 4개 투자사와 업무 협약을 체결하였고, $5 \mathrm{MW}$ 급 풍력터빈 설계 및 기술 개발을 진행 중이다. 또한 같은 해 5 월에는 세계 최초 상업용 부유식 해상풍력 발전소를 설치 및 운영 중인 노르웨이 국영기업 에 퀴노르와 협약을 맺어 부유식 해상풍력 발전단지 조성, 운영 및 유지보수 차원의 협조와 지원을 약속했다. 울산시는 이 프로젝트를 통해 일자리 창출 및 부유식 해상풍력 발전 시장 이 확대하는 것을 기대하고 있다.

(2) 제주 한림 해상풍력단지 - 제주에너지공사는 2020년 11월 월정, 행원 해상에 $100 \mathrm{MW}$ 급 이상의 해상풍력 발전단지를 조성한다고 발표했다. 약 7,500억 원의 사업비가 예상되며 제주 도 내 최대 규모이다. 이 프로젝트는 국내 연관사업의 활성화, 일자리 창출을 위해 국내 관련 업계와 협의를 거쳤으며, 풍력발 전설비를 두산중공업의 국산 기종을 설치하기로 하였다. 하지 만 제주도 내 전력 수요보다 전력공급이 많아 풍력발전기 작동 을 강제 중단하는 등 풍력발전 사업 추진에 어려움이 있다.

(3) 그 밖의 추진 중인 사업 - 국내 예정된 해상풍력발전사 업은 고창 구시포 해상풍력 $(2.4 \mathrm{GW})$, 완도 장보고 해상풍력 (400 MW), 거문도 해상풍력(8 MW 발전기 36기), 거문도, 맹골도 부유식 해상풍력 계획(각각 $400 \mathrm{MW}$ 규모), 태안해상 풍력(400 MW), 가의 해상풍력(400 MW), 서해 해상풍력(400 $\mathrm{MW})$, 안면 해상풍력(400 MW), 영광 해상풍력발전단지(50 $\mathrm{MW}, 100 \mathrm{MW}, 160 \mathrm{MW}$ 규모를 차례로 건설할 계획), 대정 해상풍력 $(100 \mathrm{MW})$ 등이 있다.

\subsection{2. 친환경적인 해상풍력 기술개발 방향}

국내 부유식 해상풍력 사업은 걸음마 단계이다. 기술 개발, 시장규모 경험 등 여러 측면에서 외국보다 많이 뒤처져 있다. 현재 국내 풍력 시장 설치 현황을 보면 국산보다 외산이 더 높은 비율을 차지하고 있으니 풍력발전 단지 설치 전 기술개발 및 주요 부품의 국산화가 선행될 필요가 있다. 또한 기술력 향상, 시장 규모 확대 등으로 설치 비용, 운영 비용이 하락할
것으로 전망하지만 현재 소모되는 비용은 수익성 확보에 어려 움을 준다. 이를 극복하기 위해 국내 두산중공업과 SK건설이 부유식 해상풍력발전단지 사업을 위한 One Team Operation (OTO) 협력체계를 시행하기로 합의했다. SK건설은 사업계획 서 개발과 인허가 취득 등 풍력발전단지 개발을 맡고, 두산은 부유식 해상풍력단지 핵심장비 제조 기술개발을 담당한다.

또한 소음, 화학물질의 누출, 해양생물의 서식지 파괴 등과 같은 이유로 인한 주민들의 반대가 심해 사업 진행에 제동이 걸리고 있다. 이러한 문제들을 해결하기 위해 2017년 9월 탐라 해상풍력발전단지 완공 이후 해양수산부가 연간 네 차례씩 해 저 생태계를 조사하고 있고, 현재까지는 남방 큰 돌고래가 관측 되는 등 생태계 이상 징후는 발견되지 않고 있다. 해상풍력발전 기 타워를 지지하는 구조물인 블랭킷은 오히려 어류의 서식지 역할을 했으며 결과적으로 해양 생태계가 더 풍부해졌다. ${ }^{29)}$ 탐라해상풍력발전 대표는 해상풍력과 함께 관광 효과까지 경험한 두모리 주민들이 해상풍력발전기 수를 늘리는 데 긍 정적인 반응을 보였으며, 제주에너지공사 등과 해상풍력발전 규모를 확장하기 위한 논의를 이어갈 계획이라고 말했다. 더 불어 기업들은 시설을 이용한 양식장 및 인공 어초 조성을 통해 주민들과 상생을 도모하여 사업을 추진해야 할 것이다.

\section{Acknowledgement}

이 연구는 대한민국 과학기술정보통신부의 재원으로 한국 연구재단의 지원을 받아 수행되었습니다(NRF-2021R1A2C1 013989).

\section{References}

1. H. J. Han, Energy transition and roles of local governments: renewable energy policy under the Moon Jae-in administration, Asia Pac. Bus., 10(1), 87-103(2019).

2. S.-H. Lee, S.-G. Yun, Review of measures to enhance local acceptance of renewable energy projects, Env. L. P., 15, 133-166(2015).

3. G. R. Yun, G. H. Lee, T. G. Ham, G. H. Lee, Offshore wind turbine and ground engineering, Geotechnical Engineering, 27(2), 8-17(2011).

4. S. H. Park, S. J. Song, H. Q. Wang, T. W. Joung, Y. S. Shin, Parametric study on scouring around suction bucket foundation, J. Ocean Eng. Technol., 31(4), 281-287(2017).

5. M. E. Kim, G. S. Lee, Current status and prospect of offshore wind power generation technology, BSNAK, 48(3), 44-50(2011).

6. M. Bilgili, A. Yasar, E. Simsek, Offshore wind power development in Europe and its comparison with onshore counterpart, Renewable Sustainable Energy Rev., 15(2), 905-915(2011).

7. B. S. Hwang, J. H. Lee, D. T. Yoo, Current status of offshore wind forces in Korea, J. Korean Soc. Steel Const., 
23(5), 7-11(2011).

8. M. Junho, J. Beomjun, L. Ojeong, S. Jaein, A study on the environmental effects of ocean wind power generation through overseas monitoring cases, J. Korean Soc. Mar. Environ., 16(4), 276-289(2013).

9. S. Degraer, R. Brabant, Offshore wind farms in the Belgian part of the north sea: state of the art after two years of environmental monitoring, Tethys Research Institute, Milano, Italy, pp. 327(2009).

10. K. Eunsung, Sensory, cultural, and institutional factors on the local acceptance of Korean wind farms, ECO, 22(1), 209-241(2018).

11. Maeil Business News, To meet offshore wind targets $\cdots$ I have to look around the coastline 4, https://m.mk.co.kr/news/ economy/view-amp/2020/10/1053711/, October(2020).

12. L. Jaeyong, Ulsan floating offshore wind power 'Equinor' Norway state-run corporation officially added: Ulsan metropolitan city-wquinor floating offshore wind power generation agreement_equinor, world's only floating head wind power generation complex, http://www.epj.co.kr/news/ articleView.html?idxno=22005, Electric Power, Gangnam, Korea(2019).

13. W. Musial, P. Beiter, P. Spitsen, J. Nunemaker, V. Gevorgian, 2018 Offshore Wind Technologies Market Report, in Proceedings of National Renewable Energy Lab, Colorado(2019).

14. S. Gourvenec, This is how we can make floating wind farms the future of green electricity, https://www.weforum.org/agen da/2020/07/floating-wind-farms-green-energy-electricity-offsh ore, January(2020).

15. J. Kumagai, With vineyard wind, the U.S. finally goes big on offshore wind power, https://spectrum.iee.org/energy/rene wables/withvineyard-wind-the-us-finally-goes-big-on-offshore -wind-power, January(2019).

16. Reuters Events, https://www.reutersevents.com/renewables/wind -energy-update/equinor-cuts-floating-wind-costs-40-design-re vamp, December(2019).

17. D. Infield, L. Freris, Renewable energy in power systems, 2nd ed., John Wiley \& Sons, Hoboken(2020).

18. D. Heo, Wind energy outlook in Europe, Trans. Korean. Inst. Elect. Eng., 61(9), 34-39(2012).

19. F. G. Nielsen, Hywind-deep offshore wind operational experience, in Proceedings of 10th Deep Sea Offshore Wind R\&D Conference, Trondheim(2013).

20. Seoul Economy, https://www.sedaily.com/NewsVIew/1VS7MY 29KK, December(2019).

21. Korea Economic TV, https://www.wowtv.co.kr/NewsCenter/ News/Read?articleId=AKR20201025000900003, October(2020).

22. Kotra, https://news.kotra.or.kr/user/globalBbs/kotranews/8/ globalBbsDataView.do?setIdx=246\&dataIdx=183560, July(2020).

23. KITA. NET, https://www.kita.net/cmmrcInfo/cmmrcNews/cmm

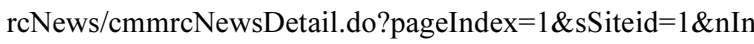
$\operatorname{dex}=\% 2060272$, October(2020).

24. offshoreWIND.biz, https://www.offshorewind.biz/2020/11/19/de utsche-bahn-taps-rwe-for-more-offshore-wind-power/, December (2020).
25. Utilities Middle East, Japan to build offshore wind plants with tenders expected soon, https://www.utilities-me.com/news/16 337-japan-to-build-offshore-wind-plants-with-tenders-expecte d-soon, November(2020).

26. ChosunBiz, Wind power generation 'waste' to be reclaimed... There is no way to dispose of waste, but it is called 'Green New Deal'?, https://biz.chosun.com/site/data/html_dir/2020/09/ 29/2020092902394.html?utm_source=naver\&utm_medium= original\&utm_campaign=biz, October(2020).

27. J. Beauson, P. Brøndsted, Wind turbine blades: an end of life perspective, Springer, Cham, Gewerbesrasse, Switzerland, pp. 421-432(2016).

28. No Tech Magazine, A world made of rotor blades, https://www.notechmagazine.com/2015/02/a-world-made-ofrotor-blades.html, February(2015).

29. D. A. Science, Offshore wind power generation emerged as an alternative to solving energy problems on the Korean Peninsula, http://dongascience.donga.com/news.php?idx=33941, Feburary(2020).

\section{Declaration of Competing Interest}

The authors declare that they have no known competing financial interests or personal relationships that could have appeared to influence the work reported in this paper.

\section{Authors and Contribution Statement}

\section{Minkyu Park}

Department of Environment and Energy Engineering, Chonnam National University, Undergraduate Student, ORCID [D 0000-00033962-9431: Data collection, Data analysis, Writing.

\section{Seongjun Park}

Department of Environment and Energy Engineering, Chonnam National University, Undergraduate Student, ORCID (1) 0000-00023865-008X: Data collection, Data analysis, Writing.

\section{Byungcheol Seong}

Department of Environment and Energy Engineering, Chonnam National University, Undergraduate Student, ORCID (1) 0000-00031262-2117: Data collection, Data analysis, Writing.

\section{Yeonjeong Choi}

Department of Environment and Energy Engineering, Chonnam National University, Undergraduate Student, ORCID (1) 0000-00026089-6780: Data collection, Data analysis, Writing.

\section{Sokhee P. Jung}

Department of Environment and Energy Engineering, Chonnam National University, Professor, ORCID \ 0000-0002-3566-5649: Supervision, Editing, Revision. 